\title{
Editorial \\ COVID: A New Peer-Reviewed Journal on Coronaviruses and Coronaviruses-Diseases
}

\author{
Shu-Kun Lin (D) and Franck Vazquez * (D) \\ MDPI, St. Alban-Anlage 66, CH-4052 Basel, Switzerland; lin@mdpi.com \\ * Correspondence: vazquez@mdpi.com
}

Citation: Lin, S.-K.; Vazquez, F. COVID: A New Peer-Reviewed Journal on Coronaviruses and Coronaviruses-Diseases. COVID 2021,

1, 1. https://doi.org/10.3390/ covid1010001

Received: 12 February 2021 Accepted: 12 February 2021 Published: 13 February 2021

Publisher's Note: MDPI stays neutral with regard to jurisdictional claims in published maps and institutional affiliations.

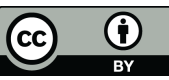

Copyright: (C) 2021 by the authors. Licensee MDPI, Basel, Switzerland. This article is an open access article distributed under the terms and conditions of the Creative Commons Attribution (CC BY) license (https:/ / creativecommons.org/licenses/by/ $4.0 /$ ).
The COVID-19 pandemic has had a tremendous effect on people around the world. In just over a year, more than 106 million cases of infections have been confirmed globally and more than 2.3 million people have died [1].

This pandemic has impacted the lives of most people on this planet. A peer-reviewed journal dedicated to coronavirus diseases (COVID) is timely and will serve as a multidisciplinary forum for peer-reviewed publication on all aspects relevant to COVID research. COVID will cover all scientific aspects relevant to COVID studies, including coronaviruses biology, physical and psychological health, and medical and clinical studies directly relevant to COVID.

COVID will complement the MDPI portfolio of biomedical journals, especially Viruses [2], Pathogens [3], and Microbiology Research [4].

As with other MDPI journals, we will maintain a fast and rigorous peer review process [5] for this new journal. We hope that you will enjoy publishing with us.

Looking forward to publishing your research work in COVID!

Conflicts of Interest: The authors declare no conflict of interest.

\section{References}

1. WHO Coronavirus Disease (COVID-19) Dashboard. Available online: https://web.archive.org/ web/20210208224808/https:/ covid19.who.int/ (accessed on 9 February 2021).

2. Viruses Homepage. Available online: https://www.mdpi.com/journal/viruses (accessed on 9 February 2021).

3. Pathogens Homepage. Available online: https://www.mdpi.com/journal/pathogens (accessed on 9 February 2021).

4. Microbiology Research Homepage. Available online: https://www.mdpi.com/journal/ microbiolres (accessed on 9 February 2021).

5. List of Publons Reviews for Journals and Conferences. Available online: https://publons.com/ journal/?order_by=reviews (accessed on 9 February 2021). 